\title{
ANALISIS VALIDITAS PERANGKAT PEMBELAJARAN MODEL OrDeP2E UNTUK MENINGKATKAN KEMAMPUAN LITERASI SAINS SISWA MAS AL-MUTAQIN WOLOWARU
}

\author{
Hamsa Doa'), Richardo Barry Astro'), An Nisaa Al Mu'min Liu1) \\ 1)Program Studi Pendidikan Fisika, FKIP, Universitas Flores, Ende, NTT, Indonesia \\ Corresponding author : Hamsa Doa \\ E-mail : hamsadoa29@gmail.com
}

\section{Diterima 20 November 2021, Direvisi 22 November 2021, Disetujui 22 November 2021}

\begin{abstract}
ABSTRAK
Penelitian ini bertujuan untuk menganalisis kevalidan perangkat pembelajaran fisika model OrDeP2E pada materi gelombang bunyi untuk melatihkan kemampuan literasi Sains siswa MAS Al-Mutaqin Wolowaru. Perangkat pembelajaran yang dikembangkan dinilai oleh dua orang. Data validasi diperoleh menggunakan penilaian perangkat dengan kategori 1-4. Penelitian ini mengacu pada pengembangan model 4-D. Perangkat yang divalidasi yaitu a) RPP, b) BAS, c) LKS, dan d) Tes Kemampuan Literasi Sains. Hasil analisis data yang sudah divalidasi menunjukkan bahwa a) RPP mendapatkan skor 3,34 (valid), a) BAS mendapatkan skor 3,52 (valid), c) LKS mendapatkan skor 3,47 (valid), d) tes kemampuan literasi sains mendapatkan skor 3,70 (sangat valid). Hasil analisis perangkat pembelajaran yang dikembangkan layak digunakan untuk meningkatkan kemampuan literasi sains siswa MAS Al-Mutaqin Wolowaru.
\end{abstract}

Kata kunci: Model Pembelajaran OrDeP2E; Validitas Perangkat Pembelajaran Fisika.

\section{ABSTRACT}

This study aims to analyze the validity of the OrDeP2E model of physics learning on sound wave material to train the science literacy skills of MAS Al-Mutaqin Wolowaru students. The learning tools developed were assessed by two people. Validation data were obtained using device ratings with categories 1-4. This study refers to the development of a 4-D model. The validated tools are a) lesson plans, b) BAS, c) worksheets, and d) Science Literacy Ability Test. The results of data analysis that have been validated show that a) RPP scores 3.34 (valid), a) BAS scores 3.52 (valid), c) LKS scores 3.47 (valid), d) tests of scientific literacy skills get a score of 3.70 (very valid). The results of the analysis of the learning tools developed are suitable to be used to improve the scientific literacy skills of MAS Al-Mutaqin Wolowaru students.

Keywords: OrDeP2E Learning Model; The Validity of Physics Learning Devices.

\section{PENDAHULUAN}

Dengan tujuan untuk menjaga kualitas Tujuan pendidikan nasional termuat dalam Pasal 3 UU No.20 tentang Sistem Pendidikan Nasional yang mendeskripsikan tentang pengembangan manusia yang beriman dan bertakwa kepada Tuhan Yang Maha Esa, bertanggung jawab, berilmu, sehat, kreatif, berakhlak mulia, cakap, kreatif, mandiri. Pendidikan berkualiatas tentunya melibatkan siswa untuk aktif dan menemukan hal yang baru dalam belajar untuk menempuh kehidupan. Siswa harus dibekali dengan kemampuan untuk belajar sepanjang hayat, belajar dari aneka sumber, belajar bekerja sama, beradaptasi, dan menyelesaikan masalah (Kemendikbud, 2016) Salah satu kemampuan yang dibutuhkan siswa yaitu kemampuan literasi sains. Kemampuan Literasi Sains (Scientific
Literacy) merupakan kemampuan yang diperlukan seseorang untuk mengambil keputusan berdasarkan bukti-bukti fisik secara ilmiah dengan mengidentifikasi memahami dan memaknai masalah tentang sains (Wenning, 2007). Menurut (PISA, 2018) literasi merupakan hasil refleksi kompetensi kognitif dari proses interpetasi dari susunan dan ciri penyajian sampai dengan pemahaman pengetahuan tentang fenomena alam.

Dengan literasi sains, siswa dapat menemukan, menanya, serta menentukan keputusan yang dikembangkan dari rasa keingintahuannya berkaitan dengan pengalaman hidupnya sehari-hari untuk dapat dimaknai. Keinginan siswa terlibat dalam penyelidikan ilmiah, kesadaran akan sains dan teknologi yang membentuk lingkungan material, intelektual dan budaya merupakan ciri 
pemahaman sains, Literasi sains memiliki 4 domain yaitu 1) domain konteks berhubungan dengan permasalah global, permasalah local dan permasalahan personal. 2) domain kompetensi menginterpretasi data dan bukti ilmiah, merencana dan mengevaluasi secara ilmiah, menjelaskan fenomena secara ilmiah. 3) domain pengetahuan yaitu pengetahuan prosedural, pengetahuan empiris dan pengetahuan konten. 4) domain afektif berhubungan dengan ketertarikan siswa dalam sains dan teknologi, menginvestigasi sains dengan pendekatan saintifik, persepsi peserta didik, dan kepekaan mereka terkait dengan masalah-masalah lingkungan (PISA, O. E. C. D., 2018).

Siswa perlu memahami literasis sains agar mereka tidak hanya memahami konsep sains saja tetapi mereka juga dapat mengaplikasikan sains dalam kehidupan sehari-hari. Literasi sains perlu dikembangkan karena setiap orang membutuhkan informasi dan berpikir ilmiah untuk pengambilan keputusan, memberikan kepuasan muncul setelah memahami dan mempelajari sains (Ardianto \& D Rubbini, B, 2016).

Berdasarkan hasil survei PISA tahun 2018 Indonesia berada di urutan paling bawah dan untuk mengetahui tingkat kompetensi siswa di ukur menggunakan indikator metode penilaian internasional, hasil menunjukan nilai kompetensi menbaca indonesdia berada pada peringkat 72 dari 77 negara yang ikur serta, kompetensi matematika, berada diperingkat ke 72 dari 78 negara dan kompetensi literasi sains, berada pada peringkat ke 70 dari 78 negera. Hal ini sejalan dengan hasil wawancara dengan guru mata pelajaran fisika MAS Al-Mutaqin Wolowaru mengatakan bahwa disekolah belum mengukur atau melatih kemampuan literasi sains.

Oleh karena perlu mengembangkan perangkat pembelajaran yang dapat melatih atau meningkatkan kemampuan literasi sains siswa. Untuk meningkatkan kemampuan peserta didik terhadap sains, maka diperlukan model pembelajaran yang melibatkan siswa dalam menemukan pengetahuan sendiri. Salah satu model pembelajaran yang memungkinkan siswa untuk menemukan dan mengembangkan konsep dan mengkombinasikan nalar dan berpikir adalah model pembelajaran OrDeP2E (Panjaitan, M.,Nur \& Jatmiko, B., 2016). Model pembelajaran OrDeP2E yang meliputi: (1) Orientasi Masalah, (2) Defenisi Masalah, (3) Pengajauan Hipotesis, (4) Pengujian Hipotesis (5) Evalauasi. Hasil penelitian (Fina Retnowati, Prabowo \& Madlazim, 2021) perangkat pembelajaran yang dikembangkan dengan model pembelajaran penemuan atau inkuiri dapat melatihkan kemampuan literasi sains siswa dan hasil penelitian (Wenning, C. J., 2007) menunjukan pembelajaran penemuan siswa diberikan kesempatan untuk menjelaskan fenomena secara saintifik, menginvestigasi, menginterpretasi data dan bukti secara ilmiah dan mengevaluasinya.

Fisika adalah pengetahuan dasar yang meliputi produk, proses serta aplikasi (Ibrahim, M., 2016). Salah satu materi dalam pembelajaran fisika yaitu gelombang bunyi. Setelah mempelajari materi tersebut terdapat tujuan yang harus dicapai siswa sesuai dengan yang tertera dalam kompetensi dasar yaitu menjelaskan gelombang bunyi dan aplikasinya dalam kehidupan sehari-hari serta penyajian data hasil percobaan untuk menyelidiki secra ilmiah. Berdasarkan tujuan tersebut, materi gelombang bunyi dapat dilaksanakan melalui pembelajaran model OrDeP2E. Melalui pembelajaran OrDeP2E siswa akan diberi kesempatan untuk menemukan konsep secara sendirii serta menghubungkannya dengan peristiwa alam dalam kehidupan sehari-hari sehingga kemampuan literasi sains siswa dapat terlatihkan.

Berdasarkan masalah diatas, peneliti melakukan penelitian untuk mengukur kevalidan perangkat pembelajaran yang dikembangkan berupa RPP, LKS, BAS dan Instrumen tes kemampuan literasi sains siswa pada materi gelombang bunyi.

\section{METODE PENELITIAN}

Penelitian ini merupakan penelitian pengembangan dengan menggunkan model 4$D$, terdiri dari empat tahap yaitu tahap pendefenisian (define), tahap perencanaan (design), tahap pengembangan (develop) dan tahap penyebaran (dessiminate) (Thiagarajan, S, \& D.S. Semmen, 1974).

Presentase kecocokan penilaian oleh dua validator terhadap perangkat pembelajaran yang dikembangkan didasarkan pada inter obsever agreement yang diperoleh dari analisis statistik percetage of agreement (R) (Borich, 1974)

$$
R=\left[1-\frac{A-B}{A+B}\right] \times 100 \% \ldots \ldots \ldots . .(1)
$$

Keterangan:

$\mathrm{R}=$ Reliabilitas

$A=$ Frekuensi validasi yang teramati dengan frekuensi tinggi

$\mathrm{B}=$ Frekuensi validasi yang teramati dengan frekuensi rendah

Instrumen tersebut dikatakan reliabel apabila memiliki reliabilitas $\geq 75 \%$.

Perangkat pembelajaran yang divalidasi meliputi: RPP, BAS, LKS, instrumen tes 
kemampuan literasi sains. Skala likert 1-4, seperti terlihat pada Tabel 1 (Ratumana, 2011).

Tabel 1 Kriteria Pengkategorian

\begin{tabular}{lll}
\hline Interval Skor & $\begin{array}{l}\text { Kategori } \\
\text { Penilaian }\end{array}$ & Keterangan \\
\hline $3,6 \leq \mathrm{P} \leq 4$ & $\begin{array}{l}\text { Sangat } \\
\text { Valid }\end{array}$ & $\begin{array}{l}\text { Dapat } \\
\text { digunakan } \\
\text { tanpa revisi }\end{array}$ \\
\hline $2,6 \leq \mathrm{P} \leq 3,5$ & Valid & $\begin{array}{l}\text { Dapat } \\
\text { digunakan } \\
\text { sedikit revisi }\end{array}$ \\
\hline $1,6 \leq \mathrm{P} \leq 2,5$ & $\begin{array}{l}\text { Kurang } \\
\text { Valid }\end{array}$ & $\begin{array}{l}\text { Dapat } \\
\text { digunakan } \\
\text { banyak revisi }\end{array}$ \\
\hline $1 \leq \mathrm{P} \leq 1,5$ & Tidak Valid & $\begin{array}{l}\text { Belum dapat } \\
\text { digunakan dan } \\
\text { masih perlu } \\
\text { konsultasi. }\end{array}$ \\
& &
\end{tabular}

\section{HASIL DAN PEMBAHASAN}

Penelitian ini bertujuan untuk mengetahui kelayakan perangkat pembelajaran dengan menggunakan model pembelajaran OrDeP2E yang dikembangkan oleh peneliti untuk meningkatkan kemampuan literasi sains siswa MAS Al- Mutaqin Wolowaru. Perangkat pembelajaran dikatakan layak ada tiga ukuran yaitu valid, praktis dan efektif. Ukuran kevalidan perangkat dilihat dari hasil validasi kelayakan perangkat pembelajaran yang nilai oleh dua akar (validator), ukuran kepraktisan perangkat dilihat dari keterlaksaan RPP, aktivitas siswa dan kendala selama pembelajaran sedangkan ukuran keefektifan dilihat dari kemampuan literasi sains dan respon siswa. Perangkat pembelajaran merupakan piranti untuk membantu dan memudahkan kegiatan pembelajaran untuk mencapai tujuan yang diinginkan (Siburian, J, Coorebima,D,A, Ibrohim \& Saptasari, M., 2019).

Validasi pengembangan perangkat pembelajaran adalah indikator kelayakan perangkat pembelajaran dalam penelitian ini adalah tingkat validitas Perangkat yang dikembangkan meliputi Rencana Pelaksanaan Pembelajaran (RPP), Lembar Kegiatan Siswa (LKS), Buku Ajar Siswa (BAS), dan Instrumen Tes Kemampuan Literasi Sains. Hasil analisis validitas pengembangan perangkat pembelajaran sebagai berikut:

\section{Validitas Rencana Pembelajaran (RPP)}

Pelaksanaan

Rencana Pelaksanaan Pembelajaran (RPP) merupakan pedoman yang dirancang sistematis untuk menggambarkan skenario penyajian materi pembelajaran (Kemendikbud, 2016). RPP yang dikembangkan adalah model pembelajaran OrDeP2E dengan lima kali pertemuan. RPP yang telah dikembangkan kemudian divalidasi oleh dua orang validator ahli dengan hasil seperti pada Tabel 2 berikut.

Tabel 2 Hasil Validasi Rencana Pelaksanaan Pembelajaran ( RPP)

\begin{tabular}{|c|c|c|c|c|c|c|}
\hline \multirow{2}{*}{ No } & \multirow{2}{*}{ Aspek yang Dinilai } & \multicolumn{2}{|c|}{ Rata-rata Skor } & \multirow{2}{*}{$\begin{array}{l}\text { Rata- } \\
\text { rata }\end{array}$} & \multirow[t]{2}{*}{ Kriteria } & \multirow{2}{*}{$\begin{array}{c}\text { Reliabilitas } \\
(\%)\end{array}$} \\
\hline & & V1 & V2 & & & \\
\hline 1 & Identitas & 4 & 4 & 4 & SV & 100 \\
\hline 2 & $\begin{array}{l}\text { Kompetensi Inti dan } \\
\text { Kompetensi Dasar }\end{array}$ & 4 & 4 & 4 & SV & 100 \\
\hline 3 & Tujuan Pembelajaran & 3 & 3,5 & 3,3 & V & 92 \\
\hline 4 & Materi Pembelajaran & 3 & 3 & 3 & V & 100 \\
\hline 5 & Model Pembelajaran & 3,5 & 3 & 3,3 & V & 92 \\
\hline 6 & $\begin{array}{l}\text { Kegiatan } \\
\text { Pembelajaran }\end{array}$ & 3,2 & 3 & 3,1 & V & 97 \\
\hline 7 & Penilaian & 2,5 & 3 & 2,6 & V & 91 \\
\hline 8 & $\begin{array}{l}\text { Sarana dan Sumber } \\
\text { Belajar }\end{array}$ & 3 & 3 & 3 & V & 100 \\
\hline 9 & Media Pembelajaran & 4 & 3 & 3,5 & V & 86 \\
\hline \multirow[t]{3}{*}{10} & Keterbacaan & 3,2 & 4 & 3,63 & SV & 90 \\
\hline & Rata-rata & & & & & $95 \%$ \\
\hline & Kategori & & & & V & Reliabel \\
\hline
\end{tabular}

Berdasarkan hasil Tabel 2 menunjukan bahwa rata-rata kevalidan RPP adalah 3,34 dengan kriteria valid dan tingkat kecocokan (precentace of agreement) sebesar 95\% berkategori reliabel. Hasil validasi RPP ini menunjukkan bahwa RPP yang dikembangkan secara umum masuk kategori layak untuk digunakan dalam pembelajaran setelah melalui 
tahap revisi sesuai saran dari validator. Revisi tersebut meliputi perbaikan beberapa kata dalam indikator, dengan menghilangkan subjek pada Indikator

\section{Validitas Lembar Kegiatan Siswa (LKS)}

Lembar Kegiatan Siswa (LKS) merupakan panduan siswa dalam melakukan kegiatan inkuiri, baik dalam pengamatan maupun penyelidikan (Akbar \& Sa'dun, 2013). Siswa dibimbing melalui pertanyaanpertanyaan/perumusan masalah, hipotesis, dan rancangan percobaan. Bimbingan yang diberikan oleh guru perlahan-lahan dikurangi sampai siswa bisa berinkuiri dengan mandiri. Analisis data hasil validasi LKS secara ringkas disajikan pada Tabel 3 berikut.

Tabel 3 Hasil Validasi Lembar Kegiatan Siswa

\begin{tabular}{|c|c|c|c|c|c|c|c|}
\hline \multirow[t]{2}{*}{ No } & \multirow{2}{*}{\multicolumn{2}{|c|}{ Aspek yang Dinilai }} & \multicolumn{2}{|c|}{ Rata-rata Skor } & \multirow[t]{2}{*}{ Rata-rata } & \multirow[t]{2}{*}{ Kategori } & \multirow[t]{2}{*}{ Reliabilitas (\%) } \\
\hline & & & V1 & V2 & & & \\
\hline 1 & Kebenaran & & 3,5 & 3 & 3,3 & $\mathrm{~V}$ & 92 \\
\hline 2 & Bahasa & & 4 & 3 & 3,5 & $\mathrm{~V}$ & 86 \\
\hline 3 & $\begin{array}{l}\text { Kesesuaian } \\
\text { dengan } \\
\text { Pembelajaran } \\
\text { OrDeP2E }\end{array}$ & $\begin{array}{r}\text { Konsep } \\
\text { Model }\end{array}$ & 3,5 & 3,7 & 3,6 & V & 97 \\
\hline \multicolumn{3}{|c|}{ Rata-rata } & & & 3,47 & & $92 \%$ \\
\hline \multicolumn{3}{|c|}{ Kategori } & & & & V & Reliabel \\
\hline
\end{tabular}

Keterangan: $\quad \mathrm{V} 1=$ Validator $1 ; \mathrm{V} 2=$ Validator $2 ; \mathrm{V}=$ Valid $; \mathrm{SV}=$ Sangat Valid

Aspek-aspek yang divalidasi dari LKS antara lain: (1) Kebenaran, (2) Bahasa, dan (3) Kesesuaian konsep dengan Model Pembelajaran OrDeP2E. Rata-rata hasil validasi Lembar Kegiatan Siswa (LKS) dari dua validator ahli pada aspek kebenaran sebesar 3,3 dengan kategori valid, aspek bahasa sebesar 3,5 dengan kategori valid, dan kesesuaian konsep dengan model pembelajaran OrDeP2E sebesar 3,6 sangat valid (Doa, H, Astro, B,R, \& Meke, P,D,K, 2020). Adapun rata-rata reliabilitas dari validasi LKS ini adalah 92\% dengan kategori reliabel. Hasil tersebut secara umum menunjukkan bahwa LKS yang telah dikembangkan layak digunakan dalam pembelajaran setelah direvisi sesuai dengan saran dari validator ahli. Revisi yang disarankan oleh validator meliputi perbaikan gambar fenomena diperjelas.

\section{Validitas Bahan Ajar Siswa (BAS)}

Bahan Ajar Siswa (BAS) yang telah dikembangkan merupakan buku panduan belajar yang digunakan baik dalam proses kegiatan pembelajaran di kelas maupun belajar mandiri (Kardi, 2012). Buku ini mencakup materi gelombang bunyi. Bahan Ajar Siswa (BAS) yang telah dikembangkan kemudian divalidasi oleh dua validator dan hasil secara singkat pada Tabel 4

Tabel 4 Hasil Validasi Buku Ajar Siswa

\begin{tabular}{llccccc}
\hline No & Aspek yang Dinilai & \multicolumn{2}{l}{ Rata-rata Skor } & Rata-rata & Kriteria & Reliabilitas (\%) \\
\cline { 2 - 4 } & K1 & V2 & & & \\
\hline 1 & Kelayakan & 3,50 & 3 & 3,3 & V & 92 \\
\hline 2 & Penyajian & 3 & 3,75 & 3,4 & V & 89 \\
\hline 3 & $\begin{array}{l}\text { Bahasa dan } \\
\text { Keterbacaan }\end{array}$ & 3,25 & 4 & 3,6 & SV & 90 \\
\hline 4 & $\begin{array}{l}\text { Aspek Model } \\
\text { OrDeP2E }\end{array}$ & 3,50 & 4 & 3,8 & SV & 93 \\
\hline Reliabilitas & & 3,52 & & $91 \%$ \\
\hline Kategori & & & V & Reliabel
\end{tabular}

Keterangan: V1 = Validator $1 ; \mathrm{V} 2=$ Validator $2 ; \mathrm{V}=$ Valid ; SV = Sangat Valid

Aspek-aspek yang divalidasi dari LKS antara lain: (1) Kebenaran, (2) Bahasa, dan (3) Kesesuaian konsep dengan Model Pembelajaran OrDeP2E. Rata-rata hasil validasi Lembar Kegiatan Siswa (LKS) dari dua validator ahli pada aspek kebenaran sebesar 3,3 dengan kategori valid, aspek bahasa sebesar 3,5 dengan kategori valid, dan kesesuaian konsep dengan model pembelajaran OrDeP2E sebesar 3,6 sangat valid (Doa, H, Astro, B,R, \& Meke, $\mathrm{P}, \mathrm{D}, \mathrm{K}, 2020)$. Adapun rata-rata reliabilitas dari validasi LKS ini adalah 92\% dengan kategori reliabel. Hasil tersebut secara umum menunjukkan bahwa LKS yang telah 
dikembangkan layak digunakan dalam pembelajaran setelah direvisi sesuai dengan saran dari validator ahli. Revisi yang disarankan oleh validator meliputi perbaikan gambar fenomena diperjelas.

\section{Validitas Instrumen Tes Kemampuan Literasi Sains}

Instrumen tes kemampuan litaresi sains dikembangkan dalam bentuk tes essay dan sesuai dengan indikator literasi sains. Indikator tes kemampuan literasi sains yaitu menjelaskan fenomena secara saintifik, mendesain dan mengevaluasi penyelidikan saintifik, dan menginterpretasikan data dan fakta secara saintifik (Ibrahim, Gunawan \& Kosim, 2020). Aspek kemampuan literasi sains yang dinilai oleh vakidator yaitu isi serta bahasa dan penulisan soal. Hasil penilaian validitas tes kemampuan literasi sains secara ringkas terlihat pada Tabel 5.

Tabel 5 Hasil Validasi Instrumen Tes Kemampuan Literasi Sains

\begin{tabular}{|c|c|c|c|c|c|c|}
\hline \multirow[t]{2}{*}{ No } & \multirow{2}{*}{$\begin{array}{c}\text { Aspek yang } \\
\text { Dinilai }\end{array}$} & \multicolumn{2}{|c|}{ Rata-rata Skor } & \multirow[t]{2}{*}{ Rata-rata } & \multirow[t]{2}{*}{ Kriteria } & \multirow[t]{2}{*}{ Reliabilitas (\%) } \\
\hline & & V1 & V2 & & & \\
\hline 1 & Isi & 3,75 & 3,50 & 3,6 & SV & 97 \\
\hline \multirow[t]{3}{*}{2} & Bahasa dan & 4 & 3,50 & 3,8 & SV & 93 \\
\hline & & ilitas & & 3,7 & & $95 \%$ \\
\hline & & yori & & & SV & Reliabel \\
\hline
\end{tabular}

Keterangan: $\quad \mathrm{V} 1=$ Validator $1 ; \mathrm{V} 2=$ Validator $2 ; \mathrm{V}=$ Valid $; \mathrm{SV}=$ Sangat Valid

Berdasarkan Tabel 3 di atas menunjukkan perolehan rata-rata hasil validasi dari 2 validator pada aspek kelayakan isi sebesar 3,3 dengan kriteria valid, aspek penyajian sebesar 3,4 dengan kategori valid, dan aspek bahasa dan keterbacaaan sebesar 3,6 dengan kategori sangat valid, serta aspek model OrDeP2E sebesar 3,8 dengan kategori sangat valid. Rata-rata reliabilitas validasi BAS sebesar $91 \%$ dengan kategori reliabel. Hasil validasi BAS menunjukkan bahwa BAS yang telah dikembangkan layak untuk dijadikan panduan siswa dalam proses kegiatan pembelajaran setelah direvisi sesuai dengan saran validator ahli. Revisi yang disarankan meliputi perbaikan penulisan kalimat yang kurang sesuai dengan ejaan yang disempurnakan (EYD), perbaikan beberapa gambar, dan referensi materi dari sumber lain.

\section{SIMPULAN DAN SARAN}

Berdasarkan hasil dan pembahasan perangkat pembelajaran fisika yang dikembangkan dengan menggunakan model pembelajaran OrDeP2E yang terdiri dari rencana pelaksanaan pembelajaran (RPP), lembar kegiatan siswa (LKS), bahan ajar siswa (BAS) dan instrumen tes kemampuan literasi sains memperoleh skor rata-rata sebesar 3,68 berkategori sangat valid dan reliabel, sehingga dapat dikatakan perangkat pembelajaran fisika materi gelombang bunyi dapat digunakan untuk tahap pengembangan selanjutnya.

\section{UCAPAN TERIMAKASIH}

Penulis mengucapkan terima kasih kepada Kemeristek Dikti/BRIN, LPPM Universitas Flores, MAS-AL Mutaqin Wolowaru Validator.

\section{DAFTAR RUJUKAN}

Akbar \& Sa'dun. (2013). Instrumen Perangkat Pembelajaran. Bandung: Remaja Rosdakarya.

Ardianto \& D Rubbini, B. (2016). Comparison of Students Scientific Literacy. Indonesian Journal of, 31-37.

Borich, G. D. (1974). Observation Skills for Effective Teaching. USA: The University of Texas.

Doa, H, Astro, B,R, \& Meke, P,D,K. (2020). Validity Analysis of the Science Learning Tools using Appoaches to Improve Creative Thinking Skill of Junior High School Student. JPF, 176189.

Fina Retnowati, Prabowo \& Madlazim. (2021). Validitas Perangkat Pembelajaran Model Inkuiri Terbimbing Untuk Melatihkan Literasi Sains Siswa. Jurnal Education and development, Institut Pendidikan Tapanuli Selatan, 331-334.

Ibrahim, M. (2016). Literasi Sains. Surabaya: UNESA Surabaya.

Ibrahim, Gunawan \& Kosim. (2020). Validitas Perangkat Pembelajaran Fisika Berbasis Model Discovery Learning Dengan Pendekatan Konflik Kognitif. J. Pijar MIPA, 214-218.

Kardi, S. (2012). Pengantar Pengembangan Kurikulum dan Rencana Pelaksanaan 
Pembelajaran. Surabaya: PPS Universitas Negeri Surabaya.

Kemendikbud. (2016). Lampiran Pendidikan Dasar \& Menengah. Jakarta: Kemendikbud.

Panjaitan, M.,Nur \& Jatmiko, B. (2016). Model Pembelajran Sains Berbasis Proses OrDeP2E untuk Meningkatkan Berpikir Kreatif dan Pemahaman Konsep Siswa SMP. Jurnal Pendidikan Indonesia, 822.

PISA, O. E. (2018). Draft Science Framework. diambil dari http://www.

Ratumana, T. (2011). Penilaian Hasil Belajar pada Tingkat Satuan Pendidikan edisi 2. Surabaya: UNESA University Press.

Siburian, J, Coorebima,D,A, Ibrohim \& Saptasari, M. (2019). Analisis validitas hasil Pengembangan Perangkat Pembelajaran IImu Pengetahuan Lingkungan Berstrategi Inkuiri dan Instrumen Tes Kemampuan Berpikir Kritis , Berpikir Kreatif dan Hasil Belajar Kognitif Mahasiswa. Biodik: Jurnal Ilmiah Pendidikan Biologi, 31- 45.

Thiagarajan, S, \& D.S. Semmen. (1974). Instructional Development for Training Center of Exceptional Children.

Wenning, C. J. (2007). Assessing inquiry skills as a component of scientific. Journal of Physics Teacher Education Online, 2124. 